\begin{tabular}{|l|l|l||}
\hline \multicolumn{2}{|c|}{ PublisherInfo } \\
\hline \hline PublisherName & $:$ & BioMed Central \\
\hline \hline PublisherLocation & $:$ & London \\
\hline \hline PublisherImprintName & $:$ & BioMed Central \\
\hline \hline
\end{tabular}

\title{
Housekeeping clusters
}

\begin{tabular}{|l|l|l||}
\hline \multicolumn{2}{|c|}{ ArticleInfo } \\
\hline \hline ArticleID & $:$ & 4476 \\
\hline \hline ArticleDOI & $:$ & $10.1186 /$ gb-spotlight-20020510-01 \\
\hline \hline ArticleCitationID & $:$ & spotlight-20020510-01 \\
\hline \hline ArticleSequenceNumber & $:$ & 142 \\
\hline \hline ArticleCategory & $:$ & Research news \\
\hline ArticleFirstPage & $:$ & 1 \\
\hline \hline ArticleLastPage & $:$ & 2 \\
\hline \hline & & RegistrationDate : 2002-5-10 \\
\hline ArticleHistory & $:$ & OnlineDate \\
\hline ArticleCopyright & $:$ & BioMed Central Ltd2002-5-10 \\
\hline \hline ArticleGrants & $:$ & \\
\hline \hline ArticleContext & $:$ & 130593311 \\
\hline \hline
\end{tabular}




\section{Jonathan B Weitzman}

Email: jonathanweitzman@hotmail.com

Operons, clustered groups of co-expressed genes, are well known in prokaryotes, but few examples exist in eukaryotic organisms. The availability of extensive transcriptome and genomic data for many eukaryotes is encouraging researchers to look more closely for clusters of co-regulated genes in higher organisms. In an Advanced Online Publication in Nature Genetics Martin Lercher and colleagues at the University of Bath, UK, report the existence of clusters of housekeeping genes in the human genome (6 May 2002, Nature Genetics DOI:10.1038/ng887). A recent study suggested that highly expressed human genes are located in clustered domains. Lercher et al. took a similar approach, examining SAGE expression profiles of over 11,000 genes in 14 different tissues. They found a high correlation between expression rate and the breadth of expression, even when they removed tandem-duplicated regions. Further analysis led them to conclude that the clusters (upto 350 kilobases long) can be accounted for by housekeeping genes (expressed in multiple tissues) rather than tissue-specific genes. The authors speculate that clustering of housekeeping genes in regions of 'open' chromatin may allow them to be coregulated in multiple cell types.

\section{References}

1. Gene clusters and polycistronic transcription in eukaryotes.

2. Nature Genetics, [http://genetics.nature.com]

3. University of Bath, [http://ww.bath.ac.uk]

4. The human transcriptome map: clustering of highly expressed genes in chromosomal domains.

This PDF file was created after publication. 